\title{
PENGEMBANGAN RESPECT EDUCATION MELALUI PENDIDIKAN HUMANIS RELIGIUS DI SEKOLAH
}

\author{
Hendro Widodo \\ Prodi PGSD FKIP Universitas Ahmad Dahlan Yogyakarta \\ Jl. Ki Ageng Pemanahan 19 sorosutan Yogyakarta \\ Email:hwpgsd1960@gmail.com
}

\begin{abstract}
Abstrak:
Pembelajaran yang berlandaskan pada mutual respek, baik dari guru kepada siswa, juga siswa kepada guru maupun antara siswa dengan siswa sendiri, akan meningkatkan loyalitas, tanggung jawab, dan solidaritas yang tinggi sehingga menciptakan suasana pembelajaran yang humanis, saling menghormati, dan menghargai satu sama lain. Artikel ini membahas secara kritis pengembangan respect education melalui pendidikan humanis religius. Pendidikan humanis religius menekankan sikap respek pada siswa, memahami, dan menghargai siswa apa adanya, mengenal siswa sebagai individu yang perlu diberikan keleluasaan untuk aktualisasi berbagai potensi kemanusiaannya.
\end{abstract}

\begin{abstract}
:
Learning based on mutual respect from teachers to students, students to teachers, and between students and students themselves will increase high loyalty, responsibility and solidarity so as to create a humane learning atmosphere, mutual respect and respect for each other. This article discusses critically the development of respect education through religious and humanistic education. Religious and humanistic education emphasizes the attitude to respect students, understand and appreciate students as they are, recognize students as individuals who need to be given the freedom to actualize their human potentials.
\end{abstract}

\section{Kata kunci:}

Respect Education, Pendidikan Humanis Religius

PENDIDIKAN pada hakikatnya merupakan upaya untuk membantu subjek didik agar berkembang menjadi sosok manusia yang potensial secara intelektual melalui proses transfer of knowledge dan potensial secara emosional dan spiritual melalui proses transfer of values yang terkandung di dalamnya. Oleh karena itu, pendidikan hendaknya mampu memperhatikan semua aspek perkembangan subjek didik sebagai manusia seutuhnya, tidak direduksi menjadi pemenuhan kebutuhan praktis sesaat.

Proses pendidikan di sekolah yang selama ini lebih dominan intelektualitas (kognitif oriented), hanyalah menghasilkan output pendidikan yang cerdas intelektual, tetapi lemah emosionalnya bahkan spiritualnya, sehingga pengembangan aspek afektif seperti akhlak, moral, etika, dan budi pekerti menjadi terpinggirkan. Padahal 
yang diharapkan dari proses pendidikan adalah menghasilkan manusia pembelajar yang anggun dari sisi moral dan unggul dari sisi intelektual. Hasil dari proses pendidikan bukan hanya cerdas secara rasional, melainkan juga cerdas secara emosional, sosial, dan spiritual. Oleh karena itu, salah satu agenda penting dalam proses pendidikan di sekolah adalah pengembangan sense of humanity dan sense of respect melalui penanaman nilai dan sikap saling menghargai, peduli pada orang lain, dan penghormatan terhadap perbedaan.

Banyak kasus yang terjadi di lapangan menunjukkan adanya dehumanisasi pada hampir setiap jenjang pendidikan. Menurut hasil penelitian yang dilakukan oleh Nansel dkk. (2001: 285) bahwa 15.686 pelajar kelas 6 sampai kelas 10 menunjukkan bahwa 30\% pelajar mempunyai indikasi melakukan bullying dan menjadi korban bullying. Penelitian lain yang dilakukan oleh Dake dkk. (2003: 173) terhadap usia sekolah dasar kelas 1-5 di 14 negara di dunia, menunjukkan bahwa prevalensi anak usia sekolah dasar yang menjadi korban bullying berkisar antara 11,3\% hingga 49,8\%. Sedangkan prevalensi pelaku bullying atau bullies berkisar antara 4,1\% hingga 49,7\%. Sedangkan hasil penelitian Hanum (2006: 56) mengenai "Fenomena Tindak Kekerasan yang Dialami Anak di Rumah dan di Sekolah" menunjukkan bahwa anak-anak pada umur di bawah 12 tahun sangat rawan terhadap tindak kekerasan dari orang tua maupun gurunya. Kekerasan yang dilakukan guru di sekolah berdampak pada hilangnya motivasi belajar dan kesulitan dalam memahami pelajaran, sehingga umumnya prestasi belajar siswa juga rendah. Kekerasan guru terhadap siswa juga menyebabkan siswa benci dan takut kepada guru. Adanya perilaku benci dan takut kepada guru, tidak saling menghargai satu dengan lainnya, dan berbagai bentuk tindak kekerasan baik yang dilakukan oleh guru kepada siswa maupun antarsiswa merupakan indikasi rendahnya respect education yang ada di sekolah.

Kondisi ini menunjukkan bahwa masih ada guru yang kurang memiliki sikap sosial seperti kurang peduli, kurang empati, tidak santun, dan kurang respek terhadap perkembangan dan keunikan peserta didik sehingga belum mampu menjadikan dirinya sebagai role model (model teladan) bagi siswanya. Oleh karena itu, perlu dikembangkan pembelajaran yang humanistik, yaitu pembelajaran yang menyadari bahwa belajar bukan merupakan konsekuensi yang otomatis melainkan membutuhkan keterlibatan mental dan berusaha mengubah suasana belajar menjadi lebih menyenangkan dan bermakna dengan memadukan potensi fisik dan psikis siswa. Beberapa keterampilan humanistik yang mendasar adalah "respect" atau respek yang sangat penting dimiliki oleh seorang pendidik dalam aktivitas pembelajarannya.

Respect education tidak hanya diperuntukkan bagi siswa melainkan juga bagi guru, sehingga menanamkan nilai-nilai respect dalam pendidikan di sekolah menjadi sangat penting, bahkan sangat tepat jika dimulai sejak dini. Artinya, sejak dini ditanamkan kepada siswa nilai dan sikap saling menghargai (respect), peduli sesama, dan menghormati perbedaan sehingga kelak diyakini bahwa pendidikan akan memberi kontribusi yang nyata dan bermakna dalam kehidupan sosialnya. 
Mengembangkan respect education di sekolah, lembaga pendidikan dalam berbagai tingkatan perlu menerapkan konsep pendidikan humanis religius. Bilamana pendidikan benar-benar ingin memanusiakan manusia secara manusiawi, maka ada dua dimensi manusia yang harus menjadi pegangan dalam pendidikan, yaitu dimensi humanis dan religius. Dimensi humanis akan mengarah pada pendidikan yang berakar pada nilai-nilai kemanusiaan, sedang dimensi religius akan membawa ke pendidikan yang berpihak pada religiusitas manusia. Oleh karena itu, melalui pendidikan humanis religius, tugas sekolah sebagai lembaga pendidikan dapat melakukan respect education secara konkret melalui proses pembelajaran di kelas maupun kegiatan persekolahan.

\section{TINJAUAN PUSTAKA}

\section{Pengertian Respect Education}

Rogers mulai mengangkat tema "Respect" dalam artikelnya yang terbit tahun 1957 (Patterson, 1985: 50-63). Dia menyebutkan bahwa respek merupakan penghargaan tanpa syarat sebagai salah satu kondisi untuk mengubah kepribadian secara konstruktif. Penghargaan positif tanpa syarat terjadi ketika seseorang tidak bergantung pada tingkah laku orang lain. Mereka dihargai sebagai seorang manusia bukan sebuah kumpulan tingkah laku. Rogers menggunakan pernyataan ini untuk menjelaskan bahwa kondisi ini termasuk di dalamnya menerima orang lain sebagai seorang manusia, dengan aspek negatif sebagaimana aspek positifnya.

Kondisi respek mengandung arti bahwa di dalamnya ada aktivitas memperhatikan, menghargai, menilai, dan menyukai. Orang lain dihargai sebagai seorang manusia yang membutuhkan respek terhadap dirinya (Patterson, 1985: 52). Aspek kondisi respek yang lain adalah nonpossessive warmth, yaitu sebuah bentuk melihat kenyataan diri seseorang dengan sebuah kepercayaan dan cinta tulus padanya. Namun, hal ini tidak bermaksud pasif atau tidak merespons. Nonpossesive warmth adalah sebuah aksi positif secara personal. Respek dapat dikomunikasikan dalam beberapa cara, seperti kehangatan dan suara yang dimodulasikan, terbuka, jujur, dan benar-benar genuine. Carkhuff dan Berenson (1967: 28) telah merasakan manfaat unconditional positive regard atau menerima tanpa syarat sebagaimana nonpossesive warmth.

Berdasarkan penjelasan di atas, respect dapat diartikan menghargai ataupun menghormati. Hal ini berkaitan erat dengan relasi antara individu satu dengan individu yang lain. Semua bentuk kekerasan tidak dapat diterima dalam hubungan personal. Menghargai diri sendiri dan orang lain merupakan bentuk sikap individu dan sosial yang positif yang harus dikembangkan dalam diri anak didik di sekolah. Dengan begitu, respect education dapat diartikan sebagai suatu proses menanamkan nilai-nilai menghargai dan menghormati orang lain untuk membangun dan menjaga hubungan yang sehat dan saling menghargai satu sama lain. 


\section{Pendidikan Humanis Religius sebagai Basis Respect Education}

Kata "humanisme" (humanism: Inggris) memiliki arti: a) aliran yang bertujuan menghidupkan rasa perikemanusiaan dan mencita-citakan pergaulan hidup yang lebih baik, b) paham yang menganggap manusia sebagai objek studi terpenting, karena paham ini menganggap individu rasional sebagai nilai paling tinggi, sebagai sumber nilai terakhir, dan mengabdi pada pemupukan perkembangan kreatif dan perkembangan moral individu secara rasional serta berarti tanpa acuan pada konsepkonsep tentang adikodrati, dan c) aliran zaman renaisans yang menjadikan sastra klasik sebagai dasar seluruh peradaban manusia. Kata "humanistik" memiliki arti pertumbuhan rasa kemanusiaan. Adapun kata "humanisasi" yang merupakan kata jadian, memiliki arti penumbuhan rasa perikemanusiaan atau pemanusiaan (Bagus, 1996: 295).

Pengertian humanisme di atas menunjukkan bahwa kata "humanis" berasal dari kata "human" yang mendapatkan akhiran "is", yang memiliki arti penganut ajaran humanisme, yaitu suatu doktrin yang menekankan kepentingan-kepentingan kemanusiaan yang ideal. Seorang humanis adalah seseorang yang selalu mendamba serta memperjuangkan sebuah kehidupan yang ideal dengan menjunjung tinggi nilainilai kemanusiaan.

Humanisme pendidikan berarti mendorong pendidikan agar dapat lebih memperhatikan aspek potensi yang dimiliki manusia (peserta didik) sebagai makhluk sosial dan religius, 'abdulläh dan khalifatulläh, serta sebagai individu yang diberi kesempatan oleh Tuhan untuk mengembangkan potensi-potensinya. Humanisme dalam hal ini adalah ranah yang dapat mengembangkan manusia sebagai individu yang dapat mengukur ranah ketuhanan dan penyelesaian problem sosial (Mas'ud, 2002: 135).

Humanisme dalam pendidikan menurut Darmiyati Zuchdi (2008: 2) adalah bentuk pendidikan yang mempertimbangkan konsepsi moralitas. Konsepsi itu meliputi kepatuhan pada hukum moral, konformitas pada aturan-aturan sosial, otonomi rasional dalam hubungan antar pribadi, dan otonomi eksistensial dalam pilihan seseorang. Keempat konsepsi itu sebagai dasar pertimbangan capaian peserta didik dalam membentuk sifat-sifat humanis.

Berdasarkan pendapat tersebut, pendidikan yang bersifat humanis adalah mengarahkan peserta didik untuk memiliki pertimbangan konsepsi moral dalam bentuk keempat itu. Jika moral berasal dari aturan-aturan religi, maka pendidikan itu esensinya mengarah ke humanis religius.

Teori humanisme tidak mengenal konsep manusia sebagai makhluk pasif. Dalam praksisnya, seorang guru yang humanis sangat menghindari adanya tindakan penekanan pada siswa. Seorang peserta didik diterima apa adanya, dengan kelebihan dan kekurangannya, sehingga tidak ada yang merasa tertekan, baik pihak siswa maupun guru, psikis maupun fisiknya. Seorang (pendidik) humanis tidak pernah menginginkan muridnya sebagai "fotokopi" dirinya. Implikasi aliran humanisme dalam pendidikan adalah keniscayaan pengembangan potensi diri peserta didik 
(Chayati, 2004: 60).

Pendidikan dengan pendekatan humanistik lebih memperhatikan siswa sebagai individu yang mempunyai kehendak atau kebebasan. Sedangkan pendekatan dehumanistik lebih cenderung memandang siswa sebagai murid bilā irādah (murid yang tidak punya kehendak). Jelasnya, pendidikan dengan pendekatan humanistik religius harus mengedepankan kebebasan siswa dalam mengekspresikan potensi insaniyahnya, yakni intelektual dan spiritual (Achmadi, 2004: 148). Dengan begitu, proses pendidikan harus menyentuh dua sisi sekaligus, yakni sisi intelektualitas dan sisi moral-spiritual. Jadi, pendekatan pendidikan humanistik religius lebih bersifat membina siswa melalui potensi yang dimilikinya, yakni potensi insaniyah yang mencakup intelektual dan spiritual.

Religius berarti bersifat religi (keagamaan) yang bersangkut-paut dengan keagamaan (Departemen Pendidikan Nasional, 2003: 944). Definisi agama digunakan oleh humanis religius secara fungsional. Fungsi agama ialah untuk melayani kebutuhan personal atau kelompok sosial. Namun, persoalan agama sering terjebak pada aspek formalitas sehingga sulit menjalankan fungsinya (Mas'ud, 2002: 131). Humanisme religius adalah sebuah konsep keagamaan yang menempatkan manusia sebagai manusia, serta upaya humanisasi ilmu-ilmu dengan tetap memperhatikan tanggung jawab habl minalläh dan habl min al-nās (Mas'ud, 2002: 193).

Orientasi religiusitas bermaksud melahirkan insan pendidikan yang dapat melaksanakan relasi vertikal dengan Allah (habl minalläh) dalam posisinya sebagai 'abdullāh, dan juga melahirkan insan pendidikan yang pada gilirannya mampu mengadakan hubungan horisontal dengan sesama manusia (habl min al-nās), serta dengan sesama makhluknya secara seimbang. Sebagai 'abdullāh dia mampu menjalankan tugas dan kewajibannya dengan baik dan benar, sehingga tidak tercabut dari kebenaran faktualnya bahwa ia bagian dari masyarakat dalam dimensi sosiologisnya. Jadi, dia harus menunjukkan kesalehan sosialnya. Islam tidak mengenal adanya humanisme sekuler, karena dalam Islam tidak ada sekularisme sehingga humanisme dalam Islam adalah humanisme religius. Humanisme dalam Islam tidak bisa lepas dari konsep habl min al-näs dan habl minalläh. Jadi, humanisme religius adalah usaha memosisikan manusia (peserta didik) agar terhormat dan menjunjung tinggi nilai kemanusiaan yang dilandasi nilai-nilai keagamaan.

Konsep humanisme religius yang diimplementasikan dalam praktik dunia pendidikan Islam akan berfokus pada akal sehat atau common sense, individualisme menuju kemandirian dan tanggung jawab, thirst for knowledge, pendidikan pluralisme, dan kontekstualisme yang lebih mementingkan fungsi daripada simbol, serta keseimbangan antara reward dan punishment (Mas'ud, 2002: 193). Keenam prinsip dasar dalam pendidikan humanis religius itu dapat dijelaskan sebagai berikut.

Pertama, common sense atau akal sehat artinya dengan akal sehatnya manusia dapat memperoleh kepercayaan dari Allah untuk menjadi khalifah di bumi ini. Hal inilah yang membedakan akal sehat yang dikembangkan di Barat karena tanpa landasan agama, dalam Islam al-'âlim lebih baik dari al-'ābid, yang notabene 
dibedakan dari akal sehatnya.

Kedua, individualisme menuju kemandirian bukan berarti acuh, tidak butuh, atau tidak menghargai orang lain, melainkan lebih menekankan pada tanggung jawab diri sendiri dan tanggung jawab kepada Allah. Pengembangan individu menjadi saleh dan insan kamil dengan berbagai keterampilan serta mandiri adalah sasaran utama pendidikan Islam.

Ketiga, Thirst for knowledge artinya pendidikan Islam harus menghargai ilmu pengetahuan tanpa mendikotomikan antara ilmu agama dan non-agama, karena Islam sangat menghargai ilmu pengetahuan, dan Islam pula yang mendorong umatnya untuk mengejar ilmu pengetahuan sampai ke negeri Cina.

Keempat, pendidikan pluralisme artinya pendidikan harus menghargai corak pendidikan yang demokratis, menghargai, dan menghormati orang lain dalam keragaman. Secara normatif, Islam menghargai dan mendukung pluralisme dan kegiatan-kegiatan cross culture, serta saling memahami antar budaya bangsa. Hal ini sesuai dengan al-Qur'an bahwa Allah menciptakan umat manusia berbangsa-bangsa dan bersuku-suku agar satu sama yang lainnya saling mengenal.

Kelima, kontekstualisme yang lebih mementingkan fungsi daripada simbol artinya harus ada keseimbangan antara simbol dan fungsi, yakni simbol yang didasari rasionalitas dan pertimbangan yang tinggi untuk mewujudkan fungsi. Dalam Islam, esensi dan fungsi tidak boleh dikalahkan oleh segala bentuk simbolisme.

Keenam, keseimbangan antara reward dan punishment artinya dalam dunia pendidikan kedua hal tersebut memang ada, tetapi dalam penerapannya harus seimbang atau lebih banyak memberi hadiah daripada hukuman dan hukuman hendaknya lebih bersifat evaluatif. Penerapan hukuman yang berlebihan akan menimbulkan anak kurang kreatif dan bahkan ketakutan, sehingga anak akan sulit mengembangkan diri.

Uraian di atas menunjukkan bahwa pendidikan humanis religius adalah pendidikan yang mampu memberikan apresiasi yang tinggi kepada manusia sebagai makhluk Allah yang mulia dan bebas, serta dalam batas-batas ekstensinya yang hakiki, termasuk sebagai khalifatulläh. Pendidikan humanis religius adalah pendidikan yang memandang manusia sebagai manusia, yakni makhluk hidup ciptaan Tuhan dengan fitrah-fitrah tertentu untuk dikembangkan secara maksimal dan optimal.

Pendidikan humanis religius bermaksud membentuk insan yang memiliki komitmen humaniter sejati, yaitu insan yang memiliki kesadaran, kebebasan, dan tanggung jawab sebagai individu, serta sebagai bagian dari masyarakat dalam dimensi sosiologisnya yang memiliki tanggung jawab moral kepada lingkungannya dalam wujud kesalehan individu dan sosial.

\section{PENGEMBANGAN RESPECT EDUCATION DALAM PEMBELAJARAN}

Pada hakikatnya guru bukanlah mengajarkan apa yang ia tahu melainkan 
mengajarkan apa yang ia miliki. Nilai-nilai respect tersebut seharusnya telah dimiliki oleh para guru sehingga mereka memiliki kewajiban moral yang melekat dengan profesi kependidikannya untuk memberikan keteladanan. Para siswa pun tidak hanya memperoleh nilai-nilai respect dari pelajaran saja yang tercetak dalam bukubuku pelajaran, melainkan juga melihat langsung bahkan meniru pada contoh perilaku guru.

Secara khusus, respect education dalam proses pembelajaran dapat dilakukan dari aspek-aspek berikut ini:

\section{Aspek Guru}

Dalam perspektif humanisme religius, guru tidak dibenarkan memandang anak didik dengan sebelah mata, tidak sepenuh hati, atau bahkan memandang rendah kemampuan siswa. Menurut Abdurrahman Mas'ud (2002: 196-197), dalam konsep pendidikan Islam humanis ini, seorang guru harus berperan sebagai orang yang mempersiapkan anak didik dengan kasih sayangnya sebagai individu yang saleh dalam arti memiliki tanggung jawab sosial, religius, dan lingkungan hidup. Guru tidak hanya sekedar melakukan transfer of knowledge atau transfer of value saja, melainkan lebih dari itu. Seorang guru harus bisa mengembangkan individu dalam rangka menerapkan dan meraih tanggung jawab. Dengan begitu, ucapan, tata bersikap, dan tingkah laku seorang guru ditujukan agar siswa bisa menjadi insan kamil.

Lebih lanjut Mas'ud (2002: 202-203) menjelaskan secara teknis guru harus melakukan hal-hal sebagai berikut: 1) guru hendaknya bertindak sebagai role model, suri teladan bagi kehidupan sosial akademis siswa, baik di dalam maupun di luar kelas; 2) guru harus menunjukkan kasih sayang kepada siswa; antusias dan ikhlas mendengar atau menjawab pertanyaan; serta menjauhkan sikap emosional dan feodal, seperti cepat marah dan tersinggung karena pertanyaan siswa sering diartikan sebagai mengurangi wibawa. 3) Guru hendaknya memperlakukan siswa sebagai subjek dan mitra belajar, bukan objek. 4) Guru hendaknya bertindak sebagai fasilitator, promoting of learning yang lebih mengutamakan bimbingan, menumbuhkan kreativitas siswa, dan interaktif serta komunikatif dengan siswa.

\section{Aspek Metode}

Di sini metode tidak hanya diartikan sebagai cara mengajar dalam proses pembelajaran bagi seorang guru, melainkan juga dipandang sebagai upaya perbaikan komprehensif dari semua elemen pendidikan, sehingga menjadi sebuah iklim yang mendukung tercapainya tujuan pendidikan. Ada beberapa poin yang berhubungan dengan sikap (bagian dari metode) yang tidak mendukung perkembangan kualitas keberagamaan anak yang biasanya ditemukan di lapangan atau dalam kehidupan sehari-hari. Misalkan di sekolah guru hanya mengejar standar nilai atau IP (mengajar berbeda dengan mendidik) sehingga kurang atau tidak memperhatikan budi pekerti anak. Para pemimpin sekolah lebih berorientasi pada pembangunan fisik sekolah daripada pembangunan manusia seutuhnya. Pendekatan otoriter, baik dari pihak 
pemimpin sekolah maupun guru. Tiada penghargaan bagi anak didik yang berprestasi, bahkan guru lebih sering menghukum. Komunikasi guru dengan anak didik hanya terjadi di kelas. Kegiatan keagamaan lebih merupakan kegiatan formalitas, insidental, tidak sistemik, dan tidak berkelanjutan. Kecerdasan anak tidak diimbangi dengan kepekaan sosial dan ketajaman spiritualitas beragama (Mas'ud, 2002: 197198).

Serangkaian fakta yang menyangkut beberapa elemen dalam pendidikan itu jelas merupakan metode mendidik dengan menggunakan paradigma lama, yakni memberi ikan, bukan mengajari cara memancing; menakut-nakuti, bukan memberi solusi; menghindari masalah bukan mendekati dan memfokuskan diri pada pemecahannya; dan bukan mengajari bagaimana cara menggunakan kunci. Metode guru dalam paradigma baru harus lebih menekankan pengembangan kreativitas, penajaman hati nurani, dan religiusitas siswa, serta meningkatkan kepekaan sosialnya. Hal ini bisa dilakukan dengan cara guru mengenal siswa secara lebih dekat sehingga individual treatment perlu dilakukan. Siswa tidak harus diperlakukan secara seragam. Kesulitannya adalah ketika guru sudah terbiasa memperlakukan kelas dengan cara yang sama, yaitu metode kolektif.

Pengembangan metode humanisme religius adalah sejauhmana guru memahami, mendekati, dan mengembangkan siswa sebagai individu yang memiliki potensi kekhalifahan, setidaknya ada beberapa hal terkait dengan permasalahan ini; 1) Cara liberating artinya guru harus membebaskan siswa dari belenggu kultur, irasionalitas, dan sebagainya; 2) cara educating artinya guru harus mampu menjadi mitra perubahan, fasilitator, dan motivator terhadap siswa, 3) cara civilizing artinya guru harus bisa menempatkan siswa pada posisi fitrahnya sebagai khalifah (Mas'ud, 2002: 202). Selaras dengan ini, Jan Lighthart (Purwanto, 2000: 145) mengatakan bahwa pendidikan harus berdasarkan cinta, sabar, dan bijaksana. Jadi, dasar yang paling diprioritaskan dalam proses pembelajaran ala humanisme religius adalah rasa kasih sayang kepada peserta didik. Juga adanya usaha memaksimalkan potensi peserta didik. Tentu hal ini harus ditunjang oleh siswa sendiri sebagai aktor perubahan, oleh guru sebagai motivator, fasilitator, konduktor, dan sejenisnya, oleh lembaga pendidikan, serta lingkungan masyarakat. Keniscayaan saling mendukung adalah sebagai syarat keberhasilan pendidikan yang humanis-religius.

Menanamkan nilai-nilai respect pada diri siswa dapat dilakukan dengan dua pendekatan, yaitu pendekatan tematik integratif dan pendekatan keteladanan atau peniruan. Pendekatan tematik integratif dilakukan dengan mengintegrasikan nilainilai respect ke dalam mata pelajaran yang memiliki tema yang sesuai dan juga dapat dilakukan melalui metode maupun strategi pembelajaran yang digunakan oleh guru. Sedangkan pendekatan keteladanan dilakukan oleh guru dengan memberikan keteladanan kepada para siswa (Widodo, 2003).

\section{Aspek Murid}

Hubungan pendidik dengan peserta didik adalah hubungan dialogis, sejajar 
antarsubjek yang saling belajar dan diajar. Keduanya dipersatukan oleh satu pandang, yakni dunia yang tengah berproses dalam gerak perubahan. Pendidik bagi peserta didik adalah partner di dalam memahami realitas tersebut. Pendidik mengemukakan persoalan agar dipertimbangkan oleh peserta didiknya. Sementara pertimbangan pendidik diuji kembali setelah ditemukan pertimbangan peserta didiknya. Peserta didik adalah teman dialog pendidik sendiri. Prasarana dan situasi yang memungkinkan dialog kritis merupakan unsur yang penting sekali dalam pendidikan.

Hal ini tidak bisa lepas dari pandangan bahwa fitrah manusia adalah bebas dan merdeka, yang menempatkan manusia sebagai pelaku atau subjek, karena fitrah manusia sejati bukanlah sebagai penderita atau objek. Untuk itu, dalam pandangan pendidikan pembebasan antara pendidik dan peserta didik sama-sama diletakkan sebagai subjek pendidikan yang sadar akan dirinya, yang sama-sama ingin mengetahui lebih banyak realitas dan pengetahuan sebagai objeknya.

Holt (Knight, 2007: 160) mengutip pandangan humanistik tentang hakikat (watak dasar) manusia (peserta didik) dan menghubungkannya dengan belajar ketika ia menuliskan bahwa anak-anak itu pada dasarnya pintar, energik, ingin tahu, besar kemauan untuk belajar, dan baik dalam belajar; bahwa mereka tidak perlu disuap dan digertak untuk belajar, bahwa mereka belajar dengan baik ketika mereka senang, aktif, terlibat, dan tertarik pada apa yang yang sedang mereka lakukan, mereka belajar kurang baik, atau bahkan sama sekali tidak baik, ketika mereka bosan, takut (diancam), dihina, dan cemas.

\section{Aspek Materi}

Bagian ini akan memfokuskan pembahasan pada satu aspek dari sekian banyak aspek pendidikan, yakni aspek materi khususnya materi pengajaran agama. Penulis berasumsi bahwa masalah utama pengajaran agama paling tidak ditandai oleh halhal sebagai berikut: 1) pengajaran materi secara umum, termasuk pengajaran agama, belum mampu melahirkan creativity, 2) Morality atau akhlak di sekolah umum masih menjadi masalah utama, dan 3) Punishment atau azab masih lebih dominan daripada reward atau ajr (Mas'ud, 2002: 206).

Materi pembelajaran tentu disesuaikan dengan tuntutan kurikulum nasional maupun kurikulum yayasan bagi sekolah swasta. Materi kurikulum yang dibelajarkan pada anak didik tidak hanya mengasah keunggulan intelektualnya saja, melainkan juga melalui penyampaian materi pembelajaran, anak didik perlu diasah perkembangan emosional dan sosialnya melalui pembelajaran di kelas.

\section{Aspek Evaluasi}

Secara umum, evaluasi selama ini berjalan satu arah, yakni yang dievaluasi hanyalah elemen siswa dengan memberi nilai semesteran. Karena masalah kultural, siswa tidak memperoleh kesempatan untuk memberi masukan balik kepada sekolah mengenai gurunya, apalagi mengevaluasi gurunya. Dalam humanisme religius, siswa 
harus dipandang sebagai individu yang memiliki otoritas individu pula, mampu mengambil keputusan yang didasari sikap tanggung jawab sejak dini. Implementasi dari sikap ini adalah suatu keharusan bahwa siswa diberi kepercayaan untuk mengevaluasi dalam rangka perbaikan ke depan apa yang ia lihat dan hadapi seharihari. Karena guru adalah mitranya yang terdekat dalam proses pembelajaran, sudah seharusnya siswa ikut andil dalam proses evaluasi guru. Hasil evaluasi para siswa sungguh lebih representatif dan objektif jika dibandingkan dengan evaluasi yang dilakukan oleh tenaga pengawas yang belum tentu sebulan sekali melakukan interaksi dengan guru.

Selama ini evaluasi terhadap siswa hanya terbatas pada ranah kognitif dan itu pun lebih berorientasi pada sejauh mana siswa mampu mengingat dan menghafal materi yang telah dikenalkan guru. Domain sikap afektif, apalagi psikomotorik, lepas dari proses evaluasi. Ini berarti proses pembelajaran hanya mengejar penumpukan materi dan informasi. Evaluasi pengajaran jelas tidak cukup hanya terpusat pada pengetahuan saja. Artinya, penilaian harus objektif dan komprehensif; bukan hanya kecerdasan intelektual, melainkan juga emosional dan spiritual.

Proses penilaian yang hanya dilakukan pada akhir semester dan midsemester juga dipandang sebagai sebuah kelemahan. Yang lebih penting adalah evaluasi harian dengan catatan mengenai perkembangan anak. Dalam pandangan humanisme religius, proses atau means lebih penting daripada end atau tujuan. Proses lebih mementingkan fungsi, bukan output yang dipaksakan, dan juga bukan mengejar nilai sebagaimana yang saat ini terjadi di sekolah-sekolah.

Dengan evaluasi sebagaimana konsep humanisme religius, baik siswa maupun guru dipandang sebagai entitas individual yang memiliki tanggung jawab vertikal dan horisontal. Dengan pandangan ini, baik siswa maupun guru sesungguhnya sama-sama memiliki tanggung jawab lebih tinggi. Ada semacam built-in motivation bagi setiap individu untuk meningkatkan kualitas pribadi agar siap dievaluasi setiap saat (Mas'ud, 2002: 213).

Menurut Eva Imania Eliasa (2010: 56-58), dalam membangun hubungan antara guru dengan siswa yang positif dan respek dalam mendukung prestasi siswa dapat melakukan hal sebagai berikut.

a. Menjaga komunikasi yang efektif dengan siswa

Respek kepada siswa dapat dilakukan dengan jalan yang terbuka, misalnya percakapan yang mendukung yang halus, juga dengan verbal dan nonverbal, seperti bahasa tubuh, pembicaraan, dan suara. Contoh, suara yang dibunyikan ketika berbicara dengan siswa menandakan seberapa tingkat respek seorang guru terhadap siswanya. Dengan berbicara yang natural atau datar, berbeda dengan berteriak atau dengan menggunakan suara yang cenderung meremehkan. Ini dapat diartikan bahwa guru respek terhadap siswa dan menghormatinya. Membangun komunikasi dengan berbagai aktivitas, seperti: 1) ketika makan siang bersama siswa; 2) menghadiri kegiatan siswa, mengirim kartu ucapan khusus (kartu ulang tahun, kartu selamat datang kembali bagi siswa yang absen, mungkin perkembangan sekarang dengan 
menggunakan handphone melalui SMS); 3) ikut merayakan ulang tahun siswa; 4) bekerja sama dalam aktivitas fisik; 5) bekerja sama dengan siswa dalam kegiatan perkumpulan siswa; 6) menggunakan kotak saran; dan 7) berhati-hati terhadap masalah yang berhubungan dengan pelecehan seksual.

b. Secara sistematik membangun hubungan lebih baik

Guru membangun hubungan yang kuat dengan siswa dalam beragam metode. Beberapa jalan yang bisa dilakukan adalah: (1) menggunakan informasi dari hasil tes atau informasi dari guru yang lain dengan hati -hati, jangan membaca informasi beberapa minggu pada tahun ajaran saja, jadi tidak langsung menghakimi siswa, berpikir kritis, dan objektif pada informasi yang terdengar janggal dari guru yang lain; (2) komunikasikan pada siswa bahwa guru percaya siswa dapat belajar dan memaknai semua pelajaran, dengan mengembalikan tugas makalahnya yang tidak memenuhi standar dan berikan saran khusus untuk perbaikan, juga apabila siswa tidak mempunyai jawaban dengan segera, tunggulah, selidiki, dan kemudian menolongnya untuk menjawab pertanyaan; (3) fleksibel dalam menggunakan strategi, dengan cara mereview hasil kerja siswa dalam kelompok yang berbeda dan bereksperimen dalam kelompok baru, menggunakan kelompok yang berbeda untuk beberapa materi pelajaran, dan menggunakan kelompok dalam latihan kerja sama ketika seluruh siswa dapat mengatasi pelajaran yang sama; (4) pastikan bahwa semua siswa dapat diberi tantangan; (5) waspada bagaimana merespons siswa yang kurang dalam diskusi kelas dengan memberi mereka pertanyaan, beri petunjuk dan waktu untuk menjawab dan memanggil siswa yang kurang sebagaimana siswa yang baik prestasinya; dan (6) berlaku adil dalam menilai dan prosedur disiplin, seperti membuat pelanggaran yang sama dengan hukuman yang sama, mencoba untuk bekerja sama dengan siswa tanpa mengetahui identitas siswa, dan menanyakan pada guru lain untuk pertimbangan.

c. Mengatasi kebutuhan nonakademik yang menghambat keberhasilan akademik siswa

Budaya akademik dan nonakademik di sekolah harus disadarkan pada guru dan siswa, bahwa keunggulan mereka dalam kedua bidang tersebut adalah suatu kebutuhan dalam proses pembelajaran. Keseimbangan dari dua keunggulan tersebut dapat menjadikan siswa lebih menerima realitas belajar bahwa setiap individu siswa dapat mengaktualisasikan potensinya dalam mencapai keunggulan tersebut. Oleh karena itu, aspek lain yang dibutuhkan siswa adalah: (1) teman di sampingnya yang perhatian pada dirinya; (2) pembelajaran yang menantang dan menyenangkan serta pengalaman bersosialisasi; (3) kesempatan untuk membuat pilihan yang tepat dan belajar bagaimana membuat pilihan yang cerdas; (4) kesempatan untuk menguasai keterampilan yang dibutuhkan untuk mengejar mimpinya dan advokasi diri, serta saling ketergantungan budaya; (5) keamanan dan kesejahteraan; (6) status dan reputasi yang baik; dan (7) kesempatan untuk mengubah kehidupan menjadi lebih baik. 


\section{SIMPULAN}

Pendidikan humanis religius menekankan sikap respek pada siswa, memahami dan menghargai siswa apa adanya, serta mengenal siswa sebagai individu yang perlu diberikan keleluasaan untuk aktualisasi berbagai potensi kemanusiaan yang dimilikinya. Pendidik yang memiliki sikap respek kepada siswa, baik di kelas maupun di luar kelas, akan membentuk pembelajaran yang menyenangkan sehingga akan lebih bermakna bagi siswanya.

Pembelajaran yang berlandaskan pada mutual respek, baik dari guru kepada siswa atau siswa kepada guru maupun antara siswa dengan siswa sendiri, akan meningkatkan loyalitas, tanggung jawab, dan solidaritas yang tinggi sehingga menciptakan suasana pembelajaran yang humanis, saling menghormati, dan menghargai satu sama lain.

\section{DAFTAR PUSTAKA}

Achmadi. (2004). Pendidikan Islam Antisipatoris. Edukasi, 2(1).

Bagus, L. (1996). Kamus Filsafat. Jakarta: PT Gramedia Pustaka Utama.

Carkhuff, R. R., \& Berenson, B. G. (1967). Beyond Counseling and Therapy. New York: Holt, Rinehart \& Winston.

Chayati, N. (2004). Menelusuri Akar Bungkamnya Daya Kritis. Edukasi, 2(1).

Dake, J. A., Price, J. H., \& Telljohann, S. K. (2003). The Nature and Extent of Bullying at School. The Journal of School Health, 73(5), 173-180. Retrieved from http://www2.gsu.edu/ wwwche/The Nature and Extent of Bullying at School.pdf.

Departemen Pendidikan Nasional. (2003). Kamus Besar Bahasa Indonesia. Jakarta: Balai Pustaka.

Eliasa, E. I. (2010). Pentingnya Sikap Respek Bagi Pendidik dalam Pembelajaran. Jurnal Pembelajaran Program Studi Teknologi Pendidikan Fakultas Ilmu Pendidikan, 1(3).

Hanum, F. (2006). Fenomena Tindak Kekerasan yang Dialami Anak di Rumah dan di Sekolah. Laporan Penelitian. Yogyakarta.

Knight, G. R. (2007). Filsafat Pendidikan. Terj. Mahmud Arif. Yogyakarta: Gama Media.

Mas'ud, A. (2002). Menggagas Format Pendidikan Nondikotomik Humanisme Religius sebagai Paradigma Pendidikan Islam. Yogyakarta: Gama Media.

Nansel, T. R., Overpeck, M., Pilla, R. S., Ruan, W. J., Simons-Morton, B., \& Scheidt, P. (2001). Bullying Behaviors Among US Youth: Prevalence and Association with Psychosocial Adjustment. JAMA, 285(16), 2094-2100. Retrieved from http://www.ncbi.nlm.nih. gov/pubmed/11311098

Patterson, C. H. (1985). Respect (Unconditional Posit ive Regard). In The Therapeutic Relationship (pp. 59-63). Monterey, CA: Brooks/Cole. Retrieved from http:// www.sageofasheville.com/pub_downloads/RESPECT_(UNCONDITIONAL_P OSITIVE_REGARD).pdf 
Purwanto, M. N. (2000). Ilmu Pendidikan Teoretis dan Praktis. Bandung: PT Remaja Rosdakarya.

Widodo, H. (2003). Menanamkan Respect Education di Sekolah. Harian Jogja.

Zuchdi, D. (2008). Humanisasi Pendidikan. Jakarta: Bumi Aksara. 